\title{
PEMIKIRAN ISLAM TERHADAP GENDER DAN PEMBERDAYAAN PEREMPUAN (Studi Pemikiran dan Model Pemberdayaan Nyai di Pondok Pesantren Nurul Jadid Paiton)
}

\author{
Siti Mahmudah Noorhayati \\ Institut Agama Islam Sahid Bogor \\ Jl. KH Abdul Hamid NKM 6, Pamijahan, 16810, Bogor \\ E-mail:afieda_2006@yahoo.co.id
}

\begin{tabular}{c|c|c}
\hline Received: & Revised: & Approved: \\
05/09/2017 & $20 / 11 / 2017$ & $04 / 12 / 2017$ \\
\hline
\end{tabular}

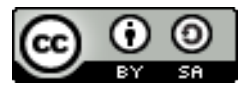

Pemikiran Islam Terhadap Gender dan Pemberdayaan Perempuan

(Studi Pemikiran dan Model Pemberdayaan Nyai di Pondok

Pesantren Nurul Jadid Paiton) is licensed under a Creative Commons

Attribution-ShareAlike 4.0 International License.

\begin{abstract}
Abstrak
Berdasarkan penelitian peneliti sebelumnya, ada beberapa model pemberdayaan perempuan yang dilakukan oleh para bu Nyai (panggilan bagi isteri kyai di lingkungan pondok pesantren), khususnya di Pondok Pesantren Nurul Jadid, Paiton, Probolinggo. Seperti, mereka terlibat melatih para wali santri puteri di lingkungan pondok pesantren, mendesain (non-participant) budaya berbasis gender dalam pembelajaran di pondok pesantren, serta terlibat aktif (full-participant) untuk menyadarkan model kehidupan berbasis gender di bagi santri puteri. Hari ini, beberapa model peran pemberdayaan itu bertambah; tidak sekedar tiga model terbatas teritorial di atas. Lebih dari itu, para bu nyai di lingkungan Pondok Pesantren Nurul Jadid, Paiton juga terlibat pada aktivitas social, ekonomi, dan politik masyarakat luas. Untuk mencapai tujuan pemberdayaan tersebut, tentunya, membutuhkan banyak pendekatan yang baru; mulai dari penyadaran terhadap masyarakat tentang
\end{abstract}


pentingnya gender, perlakukan setara terhadap perempuan, dan bagaimana cara mengoptimalisasi kekuatan serta kebersamaan yang dimiliki perempuan. Keberadaan tulisan ini adalah untuk menjabarkan bagaimana model-model pemberdayaan baru yang dilakukan para Bu Nyai di lingkungan Pondok Pesantren. Nurul Jadid, Paiton, Probolinggo. Apa persepsi yang mereka yakini tentang gender, serta bagaimana model penyampaian yang efektif untuk membentuk kesadaran gender di luar pondok pesantren berdasarkan pada nilai-nilai gender yang mereka pahami. Selain itu, penulis juga akan melakukan analisis problem terhadap perbedaan pandangan Bu Nyai yang terjadi di lingkungan Pondok Pesantren Nurul Jadid, Paiton, terkait gender dan Islam.

Kata kunci: Islam, Gender, Nyai, dan Pembedayaan Perempuan

\section{Abstract}

Of my research before, there are some models of empowerments women which are articulated by Nyai (Kyai's wife term in Pesantren), especially at Pondok Pesantren Nurul Jadid, Paiton, Probolinggo, such are; training for student mother/ parent around pesantren and designing a gendered culture and teaching-learning process inside pesantren, and giving social life experiences for women student. Nowadays, the types of empowerments were enriched, not only on three models above, but also social reconstruction, conflict resolution, economic and political contestation based on gender coalition. To do these processes, there was no easy ways except they must face unequal treatment of women in social life. So that, they had to change the normal paradigm and build the new approach to empower women outside Pesantren. This article aims to describe what paradigm they made, to reconstruct gendered stance of Islamic teaching and what model of social development approach they used, in order to make common understanding on political and social process outside Pesantren. I will discomposes Nyai of Pondok Pesantren Nurul Jadid, Paiton to three levels understanding of feminist tradition based on their conclude concept of gender. In other word, not all nyai of Pondok Pesantren Nurul Jadid, Paiton, extend their empowerment approach outside pesantren.

Keywords; Islam, Gender, Nyai, and Women Empowerment

\section{A. Pendahuluan}

Meski agak menyulitkan mengukur seberapa kuat pengaruh kajian emansipasi wanita atau kesetaraan gender mempengaruhi paradigma Bu Nyai di lingkungan pesantren, tapi nampaknya, kajian 
berbeda topik dibawah ini, bisa dirangkai sebagai wujud perubahan paradigmatik yang terhimpun di lingkungan pesantren secara umum. Siti Malikhah Towaf adalah peneliti yang paling simultan untuk menganalisa bagaimana Bu Nyai atau Nyai di pesantren (sebutan bagi istri kyai dalam tradisi pesantren) mengkonstruk paradigma gendernya. Di mulai dari tahun 2004, dia meneliti tentang bagaimana persepsi kyai terhadap gender. ${ }^{1}$ Kemudian, dikembangkan bagaimana para Nyai memahami perannya sebagai pelaksana wacana gender di tahun 2008. ${ }^{2}$ Terakhir, dia bersama peneliti lainnya, meneliti peran pesantren salaf dalam melakukan pemberdayaan berbasis gender di tahun 2011. ${ }^{3}$ Selain spesifik terkait pada peranbu nyai dan pemberdayaan berbasis gender, banyak pula riset yang bila dirangkum terkait dua topik penting yakni; kepemimpinan Nyai dan paradigma gender di lingkungan pondok pesantren. Penelitian tersebut dilakukan oleh Faiqoh, ${ }^{4}$ Muhyiddin Zainul Arifin, ${ }^{5}$ Ambarwati

${ }^{1}$ Siti Malikhah Towaf, Paparan hasil riset dalam Program dan Perencanaan Program Pemberdayaan Perempuan berwawasan Jender. Pelatihan Kepemimpinan Berwawasan Jender bagi Tim Penggerak PKK Kabupaten Gresik, Oktober 2003 dan 17-18 Juni 2004

2 Siti Malikhah Towaf, Peran Perempuan, "Peran Perempuan, Wawasan Gender dan Implikasinya Terhadap Pendidikan Pesantren" dalam Jurnal Ilmu Pendidikan UM Malang Jilid 15, Nomor 3 Tahun 2008, 142-149

${ }^{3}$ Sutatmi dan Siti Malikhah Towaf dkk, "Program Pendidikan Wirausaha berwawasan Gender berbasis Jasa Boga di Pesantren Salaf" dalam Jurnalekonomi Bisnis, Volume 16, Nomor 1 Maret 2011, 1-9

${ }_{4}$ Penelitian Faiqoh secara garis besar membicarakan tentang posisi $\mathrm{Bu}$ Nyai sebagai agen peruabahn di pesantren. Penelitian ini difokuskan untuk melihat peran isteri KH. Sahal Mahfudz yang selalu memberikan ruang diskusi dan terbuka terhadap proses pengembangan kelembagaan di pesantrennya. Dengan model seperti itu, maka peran Bu Nyai juga bisa dilihat secara signifikan untuk memberikan sumbngasih perubahan terhadap pondok pesantren. (Lihat; Faiqoh "Nyai Agen Perubahan di Pesantren" dalam Jurnal Penelitian Pendidikan Agama dan Keagamaan Volume 3 Nomor 2 Tahun 2005, 72-74)

${ }^{5}$ Dalam penelitian Muhyidin Zainul Bahri dinyatakan setidaknya ada lima peran kepemimpinan Bu Nyai di lingkungan pondok pesantren Jombang. Pertama, pelayan; Bu Nyai memiliki kewenangan dan tanggung jawab untuk menyediakan dan menjawab semua kebutuhan para santri puteri dibawah naungan kepemimpinannya. Kedua, penjaga; Bu Nyai harus menjamin keberadaan para santri puteri mengikuti semua kegiatan yang sudah dicanangkan oleh pesantren. Ketiga, pencari alur; Bu Nyai bisa melakukan inisiasi konsep pengembangan model pendidikan bagi santriwati. Keempat, penyelaras; disini peran dan pemahaman gender menjadi penting bagi $\mathrm{Bu}$ Nyai untuk mendialogkan kepentingan masyarakat umum, dan model pendidikan yang ingin dikembangkan di pesantren. Penyelaras juga memiliki makna Bu Nyai memiliki kewajiban membantu visi dan misi umum pondok pesantren sebagaimana yang sudah ditetapkan oleh para kyai. Kelima, pemberdaya; Bu Nyai berkewajiban 


\section{dan Aida Husna, ${ }^{6}$ Hatta Abdul Malik, ${ }^{7}$ Kamila Adnani, ${ }^{8}$ Noer Chalida dan Mariatul Qibtiyah AR. ${ }^{9}$}

membentuk kesadaran para santri puteri untuk memahami kehidupan bermasyarakat, khususnya berdasarkan pada peran dan tanggung jawab seorang perempuan. (Lihat; Muhyiddin Zainul Bahri "Peran Kepemimpinan Nyai di Pondok Pesantren; Studi Multi Situs di PP. Al Lathifiyah, Tambak Beras Jombang, PP. Nur Khadijah Denanyar Jomban, dan PP. Al Hikmah Kediri" dalam Jurnal SAINTEKBU: Sains dan Teknologi, Volume 7, Nomor 2 Tahun 2014, 43-44)

${ }^{6}$ Dua peneliti ini mengasumsikan bahwa idealnya pondok pesantren bisa melakukan pendidikan dan pemberdayaan berbasis pada nilai-nilai gender. Pasalnya, pesantren memiliki kepemimpinan yang terpisah antara laki-laki dan perempuan. Pondok perempuan, umumnya, dipimpin dan diasuh oleh Bu Nyai, dan secara tugas mereka memiliki intensitas yang lebih dominan daripada para kyai. Pada kesimpulan akhirnya, keduanya memberikan gagasan aplikatif bagaimana seorang $\mathrm{Bu} N y a i$ bisa melakukan komunikasi berbasis gender dan mentransformasikan pemahaman gender yang mereka miliki kepada semua santri puteri yang diasuhnya. (Lihat: Ambarwati dan Aida Husna "Manajemen Pesantren Responsif Gender; Studi Analisis di Kepemimpinan Nyai Pesantren di Kabupaten Pati" dalam Jurnal PALASTREN, Volume 7, Nomor 2 Tahun 2014, 445)

7 Hatta Abdul Malik melakukan riset berdasarkan pada tiga konstruksi penting; pertama, kaderisasi generasi muda. Kedua, peranan pesantren dan kyai. Ketiga, Reproduksi ulama' perempuan. Dalam kesimpulannya, kendati para kyai dan tradisi pendidikan di pesantren sudah mulai menghargai nilai kesamaan perlakuan terhadap laki-laki dan perempuan. Namun, keberadaannya masih tidak seterbuka terhadap pendidikan bagi laki-laki. Para santri puteri masih diberikan batasanbatasan yang bisa mengurangi akses pengetahuan mereka terhadap dunia luar. Hal inilah, yang masih menjadi pekerjaan rumah di lingkungan pesantren dalam melaksanakan kaderisasi ulama' perempuan melalui lembaga pendidikan pesantren . (Lihat: Hatta Abdul Malik "Kaderisasi Ulama' Perempuan di Jawa Tengah" dalam Jurnal At-Taqaddum, Volume 4, Nomor 1, Tahun 2012, 72-73)

${ }^{8}$ Berbeda dengan penelitian sebelumnya yang berbasis lapangan, penelitian Kamila Adnani cenderung pada kajian literature novel Perempuan berkalung Surban. Penelitian pada novel ini dilandasi karena Novel ini digarap berdasarkan pada pengalaman pemberontakan diri seorang puteri kyai di beberapa pesantren terhadap budaya perjodohan. Pada kesimpulannya, dia mengkategorikan beberapa model resistensi psikologis yang dilakukan para puteri kyai di pesantren; misalnya, persoalan masa iddah, resistensi pada keberadaan kodrat tugasnya, dan resistensi pada dominasi orang laki-laki dalam menentukan pilihan hidup pada anak perempuan (Lihat; Kamila Adnan, dkk "Resistensi Perempuan terhadap tradisitradisi di Pesantren; Analisis Wacana Kritis Terhadap Novel Perempuan Berkalung Surban" dalam Jurnal KAWISTARA, Volume 6 Nomor 2 Tahun 2016, 113-114)

9 Penelitan disertasi UIN Sunan Ampel Surabaya yang dilakukan oleh Mariatul Qibtiyah dan Noer Cholida yang membahas tentang konsep kepemimpinan dan resistensi perempuan yang ada di pondok pesantren. Lihat Mariatul Qibtiyah, "Kepemimpinan Perempuan: Peran Perempuan dalam Jejaring Kekuasaan di Pondok Pesantren Aqidah Usymuni Terate Pandian Sumenep," Disertasi (Surabaya: UIN Sunan Ampel, 2014); bandingkan dengan penelitian serupa dalam Noer Cholida, “Kepemimpinan Pada Pondok Pesantren (Studi Resistensi Bu Nyai Terhadap Patriarkhi Di Kediri," Disertasi (Surabaya: UIN Sunan Ampel, 2014). 
Dari semua riset yang sudah penulis sebutkan di atas, dapat disimpulkan bahwa melakukan kontekstualisasi paradigma gender dan model pemberdayaan perempuan di lingkungan pondok pesantren bukan lagi hal yang mustahil. Maka dari itu, penulis pun berkeinginan untuk mengembangkan hasil penelitian penulis di tempat yang sama, yakni; di Pondok Pesantren Nurul Jadid, Paiton, ${ }^{10}$ terkait bagaimana model pemberdayaan perempuan berbasis gender yang mereka laksanakan, apa saja yang ditambah karena adanya perubahan paradigma di kalangan Bu Nyai, serta bagaimana strategi yang digunakan untuk mengoptimalisasi isu gender sebagai basis pemberdayaan perempuan di masyarakat luas, dan tidak sebatas di sekitar lingkungan pondok pesantren atau hanya para santri puteri yang berdomisili di pondok pesantren. Perbedaan penulis dari yang ada sebelumnya, ada pada tiga hal penting; pertama, penelitian ini akan mencakupkan paradigma integrative (Islam, gender, dan norma pesantren) sebagai pilihan rasional para Bu Nyai untuk melakukan pemberdayaan terhadap perempuan. Kedua, aspek pemberdayaan yang dilaksanakan lebih holistik. Artinya, penelitian ini tidak sekedar akan mengulas aspek pemberdayaan ekonomi dan social semata, melainkan bagaimana pendidikan politik, resolusi konflik, dan kontestasi keduanya bisa dipahami oleh perempuan secara luas. Ketiga, situs dan konteks penelitian yang secara basis sosilogis tentu akan berbeda dari penelitian sebelumnya. Kabupaten Probolinggo, sebagaimana dimaklum, adalah daerah yang peran keagamaan dan kekuasaan kyai masih bisa diperhitungkan di kancah politik serta kehidupan sosial.

Secara metodik, dalam tulisan ini, penulis akan memakai jenis penelitian kualitatif, dengan pendekatan fenomenologis-sosiologis, serta akan dianalisis menggunakan model analisis coding. Tujuan penelitian ini, setidaknya, akan menjawab dua hal penting; corak paradigmatik terkait gender yang dipahami oleh para bunyai di lingkungan PP. Nurul Jadid, Paiton, Probolinggo, dan model serta pendekatan pemberdayaan berbasis gender yang dilakukan oleh

${ }^{10}$ Lihat S Mahmudah Noorhayati, "Pemberdayaan Perempuan dan Emansipasi Gender (Studi atas Peran Nyai dalam pemberdayaan perempuan dan Emansipasi Gender di Pondok Pesantren Nurul Jadid, Paiton Probolinggo)," Thesis , (Surabaya: IAIN Sunan Ampel, 2009). 
para BuNyai di PP. Nurul Jadid, Paiton, Probolinggo. Tulisan ini akan menggunakan purposive sampling terhadap Bu Nyai dengan model dan pemahaman gender berbeda-beda. Instrumentasi yang penulis gunakan berdasarkan pada latar belakang pendidikan, kegiatan sosial masyarakat, dan aktivitas politik yang digeluti. Terkait profiling informant tersebut penulis akan menggunakan penelitian penulis sebelumnya sebagain instrument utama menentukan informan penelitian.

\section{B. Gender, Pesantren dan Model Pemberdayaan Perempuan 1. Konsepsi Umum tentang Gender}

Diskursus gender tentu tidak hadir di ruang yang kosong. Kata gender, yang asal muasal katanya hanya bermakna, jenis kelamin pembeda antara laki-laki dan perempuan, berubah menjadi proses penyetaraan hak-hak perempuan di ruang publik; apakah itu akses kehidupan social secara luas, atau kepentingan pribadi masing-masing individu. Bagi Mansour Faqih kata gender yaitu suatu pembedaan sifat yang melekat pada kaum laki-laki maupun perempuan yang dikonstruksikan secara social maupun kultural, misalnya perempuan dikenal lemah lembut, sementara laki-laki dianggap kuat dan rasional. Pembedaan ini kemudian masih melekat hingga saat ini, sebagai stereo-typing yang ada di masyarakat luas. ${ }^{11}$ Nasaruddin Umar berkesimpulan bahwa gender adalah konsep yang dipergunakan seseorang untuk membedakan antara laki-laki dan perempuan. Gender pada pendefinisian ini diwujudkan bukan pada bentuk biologis, melainkan pada pola sikap dan sifat seseorang. ${ }^{12}$

Di atas adalah diskursus kata gender dari pengunaan kebahasaannya, dari dua definisi kebahasaan itu dapat ditarik sebuah kesimpulan bahwa gender sejatinya merupakan istilah yang sudah bergeser dari makna aslinya; dari sekedar jenis kelamin biologis, ke arah sifat dan sikap yang dimiliki oleh laki-laki dan perempuan. Bahkan, hari ini di masyarakat, kata gender sudah hilang dari kata 'berbeda' melainkan sebaliknya gender adalah 'persamaan hak

${ }^{11}$ Mansour Faqih, AnalisisGenderdanTransformasiSosial (Yogyakarta: Pustaka Pelajar, 1999), 8.

${ }^{12}$ Nasaruddin Umar, Argumen Kesetaraan Gender Perspektif al-Qur'an (Jakarta: Paramadina, 1999), 33. 
laki-laki dan perempuan' dalam hal perilaku sosial di masyarakat. Pandangan umum yang dibentuk di masyarakat ini, pastinya tidak sepenuhnya salah. Sebab, tujuan akhir dari kampanye diskursus ini adalah tuntutan para perempuan untuk diberikan akses yang berimbang dengan apa yang dilakukan oleh laki-laki. Misal, jika seorang laki-laki diberikan peluang untuk menjadi pemimpin, maka perempuan demikian. Jika seorang laki-laki bisa bekerja tanpa batasan teritori tertentu, demikian pula perempuan, dst.

Bagi penulis sendiri, mereka yang memperjuangkan kesamaan perlakuan ini (baca; kelompok feminist), asalkan tidak melawan aspek kodrati, ${ }^{13}$ maka hal tersebut merupakan hal yang lumrah dan layak diapresiasi. Namun, yang sering terjadi adalah, para pejuang perempuan ini, secara berlebihan, menonjolkan keinginan-keinginann yang melawan tugas utama mereka sendiri. Terkait dengan alasan pandangan tersebut, penulis tidak ingin banyak memperdebatkannya, sebab yang pasti, keberadaan laki-laki dan perempuan, sesuai dengan pandangan Islam, memiliki kesamaan potensi untuk meraih prestasi, sama-sama bisa menjadi pemimpin di dunia, dan samasama hamba ciptaan Allah SWT. Maka dari itu, equality adalah sebuah keniscayaan.

Adapun fakta masih ada kesenjangan paradigmatik di masyarakat tentang perlakuan berbeda bagi perempuan, sejatinya, hanya sebuah dinamika yang sangat sulit digenarilisasikan, khususnya di Indonesia sendiri. Perbedaan pandangan laki-laki terhadap peran perempuan di Indonesia cenderung dikarenakan sifat dan sikap dogmatis dan sosiologis semata. Artinya, seorang lakilaki yang mentolelir keberadaan perempuan di ruang publik, karena ajaran agama (berasaskan pada interpretasi mereka sendiri) melarang perempuan untuk beraktifitas berimbang dengan laki-laki. ${ }^{14}$ Demikian dengan faktor sosial, sejarah manusia dan kelompoknya, cenderung sudah dikonstruk kalau laki-laki berada di atas perempuan. ${ }^{15}$ Bagi

${ }^{13}$ Kodrati yang penulis maksud adalah sifat dan sikap yang tuhan sudah berikan secara melekat terhadap laki-laki dan perempuan, seperti mengandung, melahirkan, dan lain sebagainya.

${ }^{14}$ Huzaem Tahido Yanggo, Membincang Feminisme Diskursus Gender Perspektif Islam (Surabaya: Risalah Gusti, 2000), 151.

${ }^{15}$ Abdul Mustaqim, Paradigma Tafsir Feminis Membaca al-Qur'an dengan Optik Perempuan (Yogyakarta: Logung Pustaka, 2008),16. 
perempuan, yang ingin keluar dari kondisi ini, seyogyanya, mereka harus mampu menunjukkan jika konstruksi dogmatis dan sosiologiskultural tersebut tidak sepenuhnya benar. Di Indonesia sendiri, kalau semua orang ingin mengamati, keberadaan perempuan yang memiliki sifat dan sikap konsisten untuk mempertanggung jawabkan tindakannya, maka mereka pasti bisa melampaui prestasi dan capaian yang bisa didapat oleh laki-laki tersebut.

Pada intinya, diskursus gender atau bahkan perjuangan kelompok feminism, baik global maupun lokal, sedikit banyak sudah sangat merubah paradigma semua orang untuk melihat peran perempuan di ruang publik. Sejarah Islam dan Indonesia sudah mencatat bahwa, melakukan pembedaan terlalu berlebihan pada sifatsifat lemah perempuan, sudah tidak relevan lagi. Islam hadir untuk memberikan kodrat proporsional terhadap kehidupan perempuan, yang sebelumnya dalam tradisi di jazirah Arab dianggap sebagai sebuah aib. ${ }^{16}$ Di Indonesia sendiri perempuan sudah bisa tampil sebagai seorang pemimpin administrative pemerintahan, baik dalam skala nasional ataupun lokal, menjadi pemimpin di perusahaan, dan memiliki akses berimbang, bahkan tidak jarang program-program pemerintah diwajibkan untuk diisi oleh perempuan. Maka dari itu, nasib dan posisi perempuan semestinya sudah berada pada pilihan individu masing-masing. Norma masyarakat Indonesia sudah sangat terbuka bagi semua perempuan yang ingin mengaktualisasikan dirinya di lingkungan mereka masing-masing.

\section{Pesantren dan Paradigma Gender}

Seperti yang sudah diulas sebelumnya, pondok pesantren, bisa dikatakan sebagai institusi sosial-keagamaan Islam yang kurang ramah dengan tema emansipasi wanita. Pasalnya, pondok pesantren cenderung memposisikan perempuan berada di belakang (wong wingking). Pesantren memiliki nilai dan budaya yang memisahkan antara laki-laki dan perempuan. Budaya ini pun cenderung mengdiskreditkan posisi perempuan. Bagi mereka yang pernah mengenyam pendidikan pondok pesantren pasti tahu, bahwa guru

${ }^{16}$ Siti Musdah Mulia, dkk.ed, Keadilan dan Kesetaraan Jender Perspektif Islam (Jakarta: Tim Pemberdayaan Perempuan Bidang Agama Departemen Agama RI, 2001), 108-112. 
laki-laki bisa mengajar di asrama/ pemondokan puteri, tapi sebaliknya, guru perempuan dilarang mengajar di kelas/asrama putera. Di pihak yang lain, ajaran-ajaran di pondok pesantren juga ditengarai atau distigmatisasi tidak menumbuhkan kesadaran gender. Pesantren, dalam proses pembelajarannya, masih menggunakan kitab-kitab klasik yang berisi tentang peran perempuan untuk selalu patuh pada perintah laki-laki dan berada dibawah kuasa laki-laki (baca; relasi suami-isteri dalam konstruksi ilmu fiqh). ${ }^{17}$

Bukti sub-ordinasi peran perempuan di lingkungan pesantren salah satunya muncul dari pelbagai literature terkait dengan pesantren itu sendiri,misalnya, karya Endang Turmudi, Zamakhsyari Dhofier, dan Martin Van Bruinessen. Tiga penulis tentang pesantren ini tidak banyak menghadirkan peran bu nyai di lingkungan pondok pesantren. Bahkan karya Zamakhsyari Dhofier mengsakralkan kekerabatan dan keterikatan keilmuan para kyai yang disambungkan melalui tradisi orang tua laki-laki. ${ }^{18}$ Secara antropologis dan geneologis, kepemimpinan di pondok pesantren akan selalu dipasrahkan kepada mereka yang berasal dari keturunan laki-laki atau anak lakilaki. ${ }^{19}$ Ini semua menandakan bahwa pesantren, dulunya, tidak bisa menerima paradigma baru dalam konteks kajian kesetaraan akses bagi para perempuan yang juga memiliki sumbangsih dan peran di lingkungan pondok pesantren. Bahkan, ada banyak karya yang ditulis oleh perempuan pesantren, namun tidak menjadi kajian di pondok pesantren.

Hari ini, stigmatisasi dan labelisasi pesantren tidak ramah gender perlu dipikir ulang. Berdasarkan pada kajian-kajian terdahulu di atas, maka harus diakui kalau pesantren sudah mengupayakan mengikis norma-norma yang tidak prinsipil dalam konteks hubungan laki-laki dan perempuan di pondok pesantren. Tapi, untuk menghilangkan kodrat seorang perempuan dan tatanan hukum Islam yang sudah qoth'i hal tersebut masih sulit dilakukan oleh pesantren. Misalnya, pesantren tidak akan pernah merubah tatanan pembedaan

${ }^{17}$ Zamakhsyari Dhofier, Tradisi Pesantren; Studi Pandangan Hidup Kiai dan visinya mengenai masa depan Indonesia (Jakarta: LP3ES, 2011), 69

${ }^{18}$ Mufidah Ch "Pandangan Santri Ma'had Aly tentang Pengarusutamaan Gender di Pesantren Salafiyah Syafi'iayh Sukorejo, Situbondo Jawa Timur" dalam Jurnal Islamica Volume 4 Nomor 1 Tahun 2009, 78

${ }^{19} \mathrm{Ibid}, 79$ 
pemondokan antara laki-laki dan perempuan kemudian dilebur pada teritori yang sama. Yang bisa dilakukan oleh pesantren adalah memberikan perlakuan dan penyempurnaan fasilitas yang sama, bahkan lebih untuk perempuan, dalam menggapai cita-cita dan prestasi yang ingin dicapai. Misalnya saja, pesantren memberikan layanan pengalaman berdemokrasi pada siswi di lingkungan pesantren, memberikan akses pengetahuan organisasi, dan lainnya, sama seperti apa yang diimplementasikan di pondok pesantren laki-laki.

Pergeseran paradigma pesantren untuk mempertimbangkan pendidikan berbasis gender ini tidak bisa dilepaskan oleh faktor eksternal pesantren. Sebagaimana diketahui, ada sosok Gus Dur, KH. Husen Muhammad, dan beberapa pemikir islam progresif lainnya, yang dengan lantang menyuarakan agar pesantren mulai memikirkan untuk memperlakukan sama antara santri putra dan di lingkungan pesantren. Lebih-lebih, pasca isu deklarasi dan retifikasi hak asasi manusia digencarkan di Indonesia, pondok pesantren memberikan respon agar mulai merubah dan model pendidikan yang ada. Di sisi lain, di internal pesantren, para kyai pun terbuka terhadap akses dan informasi yang berkembang dengan pesantren. Stratifikasi pendidikan kyai pun meningkat, tidak hanya pada one track educational system (sekedar mendalami ilmu agama saja). Banyak kyai yang menempuh pendidikan model multi-track (baca; juga mengenyam pendidikan umum, atau berinteraksi dengan para akademisi). Keberadaan kyai yang demikian, menumbuhkan model dan jiwa baru pada cara mereka mendidik anak, memilihkan pasangan, dan mengubah tradisi sacral di pesantren. Jadi, kalau dulu para kyai memiliki menantu dari kalangan kyai juga, dan cenderung berpendidikan rendah, hari ini, para isteri kyai juga sudah tidak jarang yang memiliki gelar akademik seperti para kyai. Hal ini menambah kuat dinamika yang ada di lingkungan pondok pesantren.

Dengan demikian, sikap penulis ada pada bahasa, apapun dinamika yang terjadi di luar pondok pesantren, kyai dan semua elemen pondok pesantren selalu memiliki cara dan pendekatan yang unik dalam mendesiminasi serta menyelesaikan persoalan tersebut, termasuk di dalamnya adalah terkait dengan perkembangan kajian Hak Asasi Manusia dan gender. Dalam merespon dua isu ini, penulis 
menyimpulkan bahwa, pesantren tidak menolak konsep tersebut, karena hal itu memang penting untuk menjadikan negara ini memiliki keseimbangan dalam pembangunan kualitas manusianya, serta menyokong peradaban madani yang ada di Indonesia, melalui peran perempuan di dalamnya. Tapi, pesantren juga tidak ingin menanggalkan kodrat perempuan untuk berada berdampingan dengan laki-laki membangun rumah tangga yang baik, mengasuh dan mendidik anak. Menghormati dan mentaati perintah suami sebagai pemimpin keluarga, dan aspek-aspek lainnya, yang bisa dibangun secara equal antara laki-laki dan perempuan. Hal ini juga yang sudah sangat sering ditampakkan para kyai di lingkungan pesantren, dimana mereka memberikan ruang sedikit terbuka kepada Bu Nyai untuk berproses di dunia sosial, ekonomi, pendidikan, dan politik. Penulis kira tidak perlu ada banyak pembuktian ulang bagaimana isteri kyai memiliki peran di masyarakat di era sekarang. Sudah menjadi pengetahuan umum bagaimana isteri kyai menjadi seorang Calon Legislatif, pemimpin daerah, dan bahkan aktivis sosial dan pemberdayaan ekonomi.

\section{Arah dan Model Pembedayaan Perempuan di Indonesia}

Terlepas dari apa yang penulis jelaskan tentang istilah gender, pesantren, dan beberapa dinamika diskursusnya. Pada bagian ini, penulis ingin menggambarkan bagaimana model-model pembedayaan yang basisnya didesain berdasarkan paradigma gender. Namun sebelum itu, penulis ingin menggambarkan terlebih dahulu kenapa pemberdayaan harus didasarkan pada pembedaan jenis kelamin. Apa urgensi pemberdayaan perempuan. Serta bagaimana konsep ideal pemberdayaan perempuan; baik itu dalam skala makro, mikro, dan meso. Setelah penggambaran tersebut, barulah penulis akan menghadirkan bagaimana idealnya pemberdayaan yang mesti dilakukan oleh Bu Nyai (isteri kyai) dengan dinamika yang dihadapinya di lingkungan pesantren atau masyarakat Indonesia secara luas.

Secara teoritik, pemberdayaan bermakna memberikan kekuasaan, mengalihkan kekuatan, atau mendelegasikan otoritas ke 
pihak lain. ${ }^{20}$ Pemberian, pengalihan, dan pendelegasian ini sangat erat kaitannya dengan mikanisme atau guidelines apa yang mesti dikerjakan, bagaimana tahapan tekhnis-strategis yang harus diimplementasikan, diakhir dengan apa hasil yang diharapkan dan diciptakan. Pemberdayaan juga sangat erat dengan bahasa menggerakkan seseorang untuk melakukan perubahan pada kehidupan yang tidak dianggapnya ideal; apakah itu dalam skala individu ataupun dalam skala kelompok masyarakat. ${ }^{21}$ Bahasa lainnya lagi, pemberdayaan ialah optimalisasi kekuatan (power) yang dimiliki seseorang untuk menggerakkan orang lain melalui pendelegiasian otoritas yang dimilikinya. ${ }^{22}$ Kongkretnya, pemberdayaan merupakan sebuah proses sistemik (beralur) agar mampu merubah keadaan tertentu. Dan hal yang pelu menjadi catatan pentingnya, pemberdayaan sebenarnya berlaku umum untuk semua elemen yang dianggap kurang mampu dalam mengentaskan persoalan-persoalan yang dihadapi, tidak terspesifikasi pada jenis kelamin tertentu.

Sedang pemberdayaan perempuan, atau yang kemudian cenderung diinklusifikasi menggunakan istilah pemberdayaan berbasis gender, hadir lebih disebabkan karena faktor perempuan selalu menjadi objek kebijakan yang tidak berpihak. Perempuan 'memiliki kelemahan' dalam mengaktualisasikan potensi yang dimilikinya. Perempuan 'diidentikkan' sebagai korban kebudayaan yang tidak sadar akan pentingnya berpartisipasi dalam pembangunan dan pengembangan masyarakat sekitar. Perempuan, dalam tradisi budaya dan dogma, lebih suka diposisikan sebagai manusia yang lemah dan tidak bergerak secara merdeka. Kesan-kesan ilmiah inilah yang melatari kenapa pemerintah, masyarakat global, dan kelompok masyarakat tertentu, menganggap perlu pemberdayaan perempuan ini diberlakukan secara optimal. Secara subjektif penulis pun merasa perlu bahwa pembedayaan perempuan ini dilakukan; sedikitnya, tujuan akhir pemberdayaan perempuan ada pada

${ }^{20}$ Petter Oakley \& David Marsden, Approaches to Participation in RuralDevelopment (Geneva: t.p., 1984), 120.

${ }^{21}$ Jamaluddin Malik, Ed., Pemberdayaan Pesantren Menuju Kemandirian dan Profesionalisme Santri dengan Metode Daurah Kebudayaan (Yogyakarta: Pustaka Pesantren kerja bareng dengan Yayasan Kantata Bangsa, 2005), 33.

${ }^{22}$ Ginanjar Kartasasmita, Pembangunan Untuk Rakyat (Jakarta:Pustaka CISENDO, 1996), 208. 
mengubah paradigma dari objek menjadi subjek dalam kehidupan sosial- kemasyarakatan.

Dari paradigma di atas, Bhasin, dalam Sushama Sahay, mengatakan bahwa makna pemberdayan perempuan adalah; menyadarkan kembali kontribusi perempuan dan pengetahuannya, menolong perempuan untuk melawan ketakutan yang mereka hadapi, membangkitkan semangat untuk berkontribusi terhadap sesama, menyadarkan agar perempuan bisa mengontrol dirinya sendiri, meningkatkan kemampuan ekonominya agar bisa mandiri, meghilangkan batasan pemahaman perempuan sebagai penjaga rumah tangga semata, dan menciptakan serta menguatkan perempuan melalui proses institusionalisasi dan organisasi. ${ }^{23}$ Pada intinya, pemberdayaan perempuan bisa diartikan sebagai proses penyadaran bahwa peranannya tidak bisa dibatasi oleh dogma dan norma sosial yang cenderung mendeskreditkan kontribusi mereka. Pemberdayaan perempuan juga bisa berarti penguatan pola kehidupan secara mandiri, baik itu melalui pematangan kehidupan pribadi ataupun kelompok.

Untuk dapat melaksanakan hal tersebut, tentu tahapan paling utama adalah merubah mindset semua kalangan tentang apa peran perempuan sebenarnya. Bukan sekedar dalam tataran wacana sebagaimana yang sudah disebutkan sebelumnya. Bahkan harus bisa lebih konkret, laiknya yang dilakukan oleh para kelompok feminist radikal di beberapa negara maju. ${ }^{24}$ Mereka melakukan gerakan kolektif dan membuat keputusan individu yang bisa dikatakan menyalahi normatifitas kehidupan sosial dan agama. Kesadaran kolektif tersebut menurut Hall akan bisa tercapai melalui perangkat strategis sebagaimana berikut:

a. Pemberdayaan perempuan harus diarakahkan untuk mendefinisikan perilaku, nilai dan tindakan yang berhubungan dengan kepentingan mereka sendiri. Kata kebebasan dan kemandirian harus memiliki nilai hirarkis dengan nilai sosial dimana mereka hidup; apakah itu di

${ }^{23}$ Sushama Sahay, Women and Empowerment Aprroaches and Strategies (New Delhi: Discovery Publishing House, 1998), 9

${ }^{24}$ Laporan utama Ancaman Feminisme Radikal diakses melalui http:// www.majalahsaksi.com/pdf.php?id=63 Pada 23 Maret 2017 
kalangan modern yang memiliki keterbukaan sikap ataupun dalam kondisi tradisional;

b. Pemberdayaan perempuan diarahkan untuk me-mentain mindset equality, bukan kemudian melawan dan berkonfrontasi dengan dominasi yang dimiliki oleh seorang laki-laki. Sebab, kata equality akan lebih menyeimbangkan antara paradigma yang dibangun seorang laki-laki terhadap perempuan itu sendiri;

c. Pemberdayaan perempuan, seyogyanya, dimulai dari mengidentifikasi talenta untuk bisa memenuhi kehidupan sendiri. Pemberdayaan perempuan harus bisa menampakkan kekuatan dirinya di dalam bingkai dominasi ajaran agama, tugas, dan nilai-nilai sosial yang mengikat mereka.

d. Pemberdayaan perempuan, harus diintegrasikan dengan tanggung jawab sebagai seorang ibu rumah tangga dan bisa berpartisipasi dengan nilai-nilai keagamaan. Bukan sebaliknya, pemberdayaan dipaksakan untuk menghilangkan peran perempuan di rumah, atau menjadi antipasti pada aktivitas keagamaan yang dijalankan di lingkungan masyarakat.

e. Pemberdayaan perempuan harus bisa menciptakan kepercayaan diri. Mereka diajak untuk menyadari bahwa ada moral visions yang dilakukan, bahkan dikala mereka harus berhadapan dengan nilai otoritatif dari seorang lakilaki. Sebut saja misalnya, pemimpin rumah tangga di rumah mereka masing-masing.

f. Pemberdayaan perempuan mesti dilaksanakan dengan melibatkan kelompok masyarakat dan dijalankan secara bersama-sama. Sebab, dengan seperti itu, mereka akan lebih mudah mentransformasikan sikap-sikap individu menjadi bagian kehidupan sosial (parts of collective actions in society). ${ }^{25}$

Tawaran Hall ini memang lebih konfrehensif dibandingkan dari model-model gerakan feminisme yang sudah penulis katakana sebelumnya. Jika perangkat strategis tersebut diimplementasikan ke ruang pesantren atau untuk menilai apa yang dilakukan oleh

${ }^{25}$ C. Margaret Hall Women and Empowerment ; Strategies For Increasing Authonomy (London: Himesphere Publishing Corp. 1992), 95 
Bu Nyai dalam konteks beberapa penelitian sebelumnya, maka kontroversi terhadap paradigma kesetaraan laki-laki dan perempuan di lingkungan pondok pesantren tidak relevan lagi. Sebab, penelitian Towaf dkk, termasuk mereka yang mengangkat kajian tentang kepemimpinan perempuan di pesantren, tidak ditigmatisasikan sebagai wujud perlawanan pada dominasi yang sudah menjadi hak para kyai. Keberadaan mereka cenderung dikarenakan dorongan kuat dari diri sendiri, serta iklim sosial yang memperbolehkan mereka untuk melakukan tindakan tersebut. Penulis pun bersepakat, bahwa pemberdayaan perempuan - dalam rangka untuk membentuk kesadaran dan kemandirian sikap - sesuai dengan pemahaman keperempuanan kodrati, tidak akan menjadi persoalan bagi semua orang, termasuk mereka yang masih memegang teguh nilai-nilai tradisionalisme dan keagamaan kuat di Indonesia.

\section{Potret Pemberdayaan Perempuan dan Peran $B u$ Nyaidi PP. Nurul Jadid, Paiton, Probolinggo}

Pondok Pesantren Nurul Jadid, Paiton, ${ }^{26}$ secara kategoris, tergolong sebagai pondok pesantren yang modern dalam makna pengintegrasian pendidikan formal di lingkungan pesantren. Hampir semua lembaga formal dari setiap tingkatan tersedia di lembaga yang didirikan oleh KH. Zaini Abdul Mun'im ini; mulai dari Pendidikan Anak Usia Dini (PAUD), Raudlatul Athfal hingga Perguruan Tinggi Islam atau umum sekalipun. Secara internal, dinamika kepengasuhan dan tradisi yang ada juga sangat fleksibel. Artinya, ada keterbukaan yang diberikan pesantren kepada semua elemen di pesantren untuk

${ }^{26}$ Pondok Pesantren Nurul Jadid, Paiton Probolinggo pada tahun 1949 oleh KH. Zaini Mun'im setelah melakukan rihlah ilmiah dan spiritual ke dua pondok pesantren yang lebih tua sebelumnya, yakni PP. Salafiyah Syafiiyah Sukorejo dan PP. Zainul Hasan Genggong. Visi Pondok Pesantren Nurul Jadid Paiton Probolinggo adalah terbentuknya manusia yang beriman, bertaqwa, berakhlaq al karimag, berilmu, berwawasan luas, berpandangan kedepan, cakap, terampil, mandiri, kreatif, memiliki etos kerja, toleransi, bertanggungjawab kemasyarakatan, serta berguna bagi agama, bangsa dan negara. Trilogi Santri : 1) Berkomitmen pada kewajiban Fardlu 'ain, 2) Berkomitmen dalam meninggalkan dosa-dosa besar, dan 3) Berakhlaq mulya pada Allah dan Makhluq-Nya. Panca Kesadaran Santri : 1) Kesadaran Beragama, 2) Kesadaran Berilmu, 3) Kesadaran Bermasyarakat, 4) Kesadaran Berbangsa dan Bernegara, 5) Kesadaran Berorganisasi. (lihat Panduan Wali Santri Pondok Pesantren Nurul Jadid Paiton Probolinggo (Lihat; Buku Pedoman Santri Nurul Jadid Paiton atau kunjungi website resmi PP. Nurul Jadid; nuruljadid.net) 
mengaktualisasikan diri; apakah itu santri ataupun para 'pembantu' pondok pesantren. Di sisi yang lain, ada beberapa kyai yang memiliki keterlibatan di dalam koncah perpolitikan dan pemberdayaan sosial masyarakat sekitar. Untuk pemberdayaan masyarakat, Pondok Pesantren Nurul Jadid, Paiton Probolinggo, (selanjutnya disingkat PP. Nurul Jadid, Paiton) memiliki lembaga Biro Pemberdayaan dan Pengembangan Masyarakat (BP2M). Lembaga ini concern terhadap peran pesantren untuk melakukan pemberdayaan masyarakat sekitar. Lembaga ini didirikan oleh KH. Abdul Wahid Zaini sebagai pengasuh ketiga di PP. Nurul Jadid.

Terkait dengan pemberdayaan perempuan, PP. Nurul Jadid, Paiton, secara institusional, memiliki lembaga Pusat Studi Wanita (PSW) ${ }^{27}$ kendati lembaga ini berada di bawah naungan IAINurul Jadid, Paiton, tidak langsung berada di bawah naungan pondok pesantren. Sebagaimana data yang penulis dapatkan tugas Pusat Studi Wanita ini adalah "Mengangkat derajat perempuan, memberdayakan potensinya dan perlakuan yang baik, wajar dan berkeadilan (mu'asyarah bi al$m a^{\prime}$ ruf) dengan landasan konsepsionalnya sebagai berikut:

1. Teologis: Nilai-nilai universal al-Qur'an dan Hadis

2. Konstitusional: UUD'45 BAB x, pasal 27

3. Operasional: TAP MPR tahun 1999

a. Meningkatkan kedudukan dan peranan perempuan dalam kehidupan berbangsa dan bernegara melalui kebijakan

${ }^{27}$ Fenomena ini direspon positif oleh IAI Nurul Jadid, yang bermula dari motivasi ketika dikirimnya delegasi untuk mengikuti Lokakarya "Mencari Paradigma Pengembangan Pendidikan Tinggi Nasional Dalam Konteks Budaya Keindonesiaan" yang disampaikan oleh Presiden KH. Abdurrahman Wahid pada tanggal 17 April 2001 di Malang, sehingga terbentuklah lembaga yang berbasis keagamaan bercorak teologi feminis, sebagai himpunan produk kajian wanita di lingkungan IAI Nurul Jadid. PSW IAI Nurul Jadid menggali materi yang bersumber dari nilai-nilai Islam. Metodologi dan analisis yang diadopsi dari Barat sebatas kebutuhan yang sifatnya melengkapi, dan tetap berpegang teguh pada nilai-nilai universal Islam seperti keadilan, kemanusiaan, kesetaraan demokrasi, kesusilaan, dsb. Lahirnya PSW ini, tidak lepas dari fenomena ketimpangan dalam memahami gender yang bercokol secara kokoh di masyarakat, baik yang disebabkan faktor konstruksi sosial masyarakat maupun interpretasi teks agama yang didekati dengan cara yang kurang sesuai dengan pesan-pesan Tuhan yang termuat dalam teks itu sendiri, sehingga kurang singkron dengan pesan-pesan universal Islam, seperti keadilan, kemanusiaan, kesetaraan demokrasi, kesusilaan, dan sebagainya. Demikian pula isu global yang ikut mendorong keberadaan PSW melalui tulisan, media elektronik, maupun internet. (Diolah dari hasil wawancara dengan Nyai Khodijatul Qodriyah Hamid pada tanggal 04 Juni 2017) 
nasional yang diemban oleh lembaga yang mampu memperjuangkan terwujudnya kesejahteraan dan keadilan gender.

b. Meningkatkan kualitas peran dan kemandirin organisasi perempuan dengan tetap mempertahankan nilai persatuan dan kesatuan serta nilai historis perjuangan kaum perempuan, dalam rangka melanjutkan usaha pemberdayaan serta kesejahteraan keluarga masyarakat.

PSW IAIN mencita-citakan masyarakat yang menjamin terciptanya relasi yang berkeadilan gender ( $m u^{\prime}$ asyarah bi al-ma'ruf) yang berperspektif Islam. Karenanya, PSW secara konsisten akan berupaya mewujudkannya di tengah-tengah masyarakat sesuai dengan ruh dan semangat Tri Dharma Perguruan Tinggi.Sejalan dengan misi PSW di atas, maka arah kegiatan PSW IAI Nurul Jadid adalah sebagai berikut:

1. Pendidikan dan Penelitian. Membangun wacana gender yang berperspektif Islam (dengan melakukan pelatihan dan pengiriman delegasi pada kajian-kajian yang sevisi); Pendidikan perempuan dan penelitian yang berhubungan dengan program pemberdayaan perempuan; Penelitian pustaka atau lapangan berwawasan gender yang menyentuh seluruh bidang kehidupan, misalnya: penelitian tentang kesehatan dan hak-hak reproduksi perempuan, hukum dan perundang-undangan, perempuan dan media massa, profil perempuan disesuaikan dengan kondisi obyektif lokal.

2. Pengabdian dan Pengembangan Masyarakat Konseling; Aktif memberikan masukan pada penyusunan propeda dan perda khususnya di tingkat lokal; Sosialisasi penghapusan kekerasan terhadap perempuan; Pemberdayaan forum peduli perempuan dan anak; Penguatan hak-hak reproduksi; Bimbingan praktis peningkatan kesejahteraan keluarga.

Untuk mendukung kualitas keberhasilan program, PSW membangun jaringan kerjasama dengan organisasi-organisasi pemerintah dan non pemerintah pada tingkat lokal maupun nasional; instansi pemerintahan, lembaga pendidikan, media massa, dan elemen-elemen yang concern kepada perempuan dan anak. Dalam 
hal ini, para nyai secara struktural duduk di Dewan Pengawas dan Dewan Pertimbangan dan melakukan monitoring terhadap berbagai aktifitas PSW IAI Nurul Jadid. ${ }^{28}$

Adapun perkumpulan internal di lingkungan PP. Nurul Jadid dalam hal pemberdayaan perempuan dibentuk melalui institusi bernama Ikatan Perempuan Yayasan PP. Nurul Jadid, Paiton. ${ }^{29}$ Dibandingkan dengan PSW IAI Nurul Jadid, Paiton, perkumpulan ini cenderung tidak formal. Diskusi dan perangkat berfikir yang dilaksanakan berbasis pada model-model kekeluargaan diantara semua elemen yang ada di PP. Nurul Jadid, Paiton. Salah satu kegiatan yang intens dilaksanakan misalnya, pelatihan-pelatihan keterampilan bagi orang tua santri atau isteri dari pengabdi dan pengurus yang ada di lingkungan PP. Nurul Jadid, Paiton. Pada institusi ini pula, kemudian, semua orang bisa melihat bagaimana peranan para $B u$ Nyai dalam menguatkan sikap kemandirian dan pemahaman perempuan di lingkungan PP. Nurul Jadid. Sebab, interaksi yang ada di perkumpulan ini hanya terbatas bagi kelompok perempuan saja, tidak boleh melibatkan laki-laki yang menjadi kepala keluarga masing-masing isteri.

Untuk lebih mengkonkritkan apa yang penulis ungkapkan sebelumnya, penulis juga melakukan wawancara mendalam kepada hampir semua isteri kyai yang ada di PP. Nurul Jadid, Paiton.

${ }^{28}$ Tim Penyusun buku Panduan PSW IAI Nurul Jadid "Selayang Pandang Pusat Studi Wanita IAI Nurul Jadid" (Probolinggo: LPM IAI Nurul Jadid Press, 2013). 2

${ }^{29}$ Tujuan pendirian kelompok ini adalah terwujudnya muslimah yang aktif dengan memiliki komitmen panca kesadaran, yaitu; beragama, berilmu, bermasyarakat, berbangsa dan bernegara yang berakhlaqul karimah menjadi visi dari organisasi ini. Sementara misinya yaitu melaksanakan pendidikan pada perempuan di PP. Nurul Jadid dalam upaya membentuk muslimah yang berilmu dan berbudi luhur. Menyelenggarakan pendidikan dan kajian agama untuk membentuk muslimah agar dapat menciptakan keluarga sakinah dan maslahah. Melakukan kegiatan sosial dalam rangka membentuk kesadaran bermasyarakat. Melakukan penelitian masalahmasalah perempuan dan pemecahannya. Keanggotaan yang masuk di dalamnya dibagi menjadi dua, yaitu anggota biasa yang secara otomatis menjadi anggota Ikatan Perempuan Yayasan Nurul Jadid yang terdiri dari pengurus putri, guru perempuan, karyawan atau abdi perempuan dan istri-istri dari guru, pengurus, karyawan yang ada di lingkungan PP. Nurul Jadid. Sedangkan anggota luar biasa adalah anggota yang dengan sengaja mendaftarkan diri sebagai simpatisan dan partisipan ke PP. Nurul Jadid. 
Mereka adalah Nyai Masrurah, ${ }^{30}$ Nyai Aisyah, Nyai Zubaidah Taha, ${ }^{31}$ Nyai Bisyarah Taha, ${ }^{32}$ Nyai Nuri Firdausiyah, ${ }^{33}$ Nyai Syadidah, ${ }^{34}$ Nyai Hamidah Wafi, ${ }^{35}$ Nyai Latifah Wafi. dan Nyai Khadijatul Qadriyah Wahid. ${ }^{36}$

Paradigma Hall dalam melaksanakan pemberdayaan perempuan dilaksanakan secara seksama oleh para Bu Nyai yang ada di lingkungan PP. Nurul Jadid, Paiton. Paradigma integratif antara gender dan Islam dipahami sebagai sebuah keniscayaan. Gender punya konsekwensi untuk menyamakan (equality) harkat dan martabat perempuan secara proporsional. Demikian halnya dalam dimensi keislaman. Sejarah Islam hadir dalam kondisi kesejarahan dan dinamika sosial yang menganggap perempuan sebagai aib dan korban patologi budaya patriarki. Islam mengangkat derajat perempuan dan mendelegasikan semua otoritas yang dimiliki manusia dalam koridor kodrati (ketentuan tuhan). Islam mendudukan perempuan bukan pada posisi yang lebih rendah, sebaliknya, berada pada kondisi keberimbangan di ruang publik dan akses untuk mengaktulisasikan dirinya. Pemahaman-pemahaman yang seperti inilah yang banyak diungkapkan oleh para informan di PP. Nurul Jadid, Paiton. Apakah itu Bu Nyai yang memiliki pemahaman dan pemikiran progresif, atau malahan yang tradisional sekalipun.

Adapun dari spacing point of empowerment para Bu Nyai di lingkungan PP. Nurul Jadid, Paiton tetap terbagi sesuai dengan peran territorial mereka sendiri. Hal ini tidak berubah dari penelitian penulis

\footnotetext{
${ }^{30}$ Nyai Masruroh adalah seorang janda dari Kiai (alm) Hasyim Zaini, pengasuh ke-2 PP. Nurul Jadid. Secara territorial, dia merupakan pengasuh Dalem Timur (Daltim). Dia memiliki kewenangan untuk membuat aturan-aturan spesifik yang ada di Daltim (sebutan khas di PP. Nurul Jadid Paiton terhadap asrama puteri ini)

${ }^{31}$ Nyai Zubaidah Thaha adalah istri dari pengasuh ketiga PP. Nurul Jadid yaitu (alm) KH. Abd. Wahid Zaini.

${ }^{32}$ Nyai Bisyaroh adalah istri pengasuh ke empat PP. Nurul Jadid (saat ini) yaitu KH. Zuhri Zaini.

${ }^{33}$ Nyai Firdausiyah adalah istri dari ketua yayasan Nurul Jadid saat ini yaitu (alm) KH. Abdul Haq Zaini. Beberapa tahun silam beliau menetap di Mekah dimana tempat kiai menimba ilmu.

${ }^{34}$ Nyai Syadidah Thaha adalah istri dari (alm) KH. Nur Chatim Zaini.

${ }^{35}$ Nyai Hamidah adalah salah satu generasi ketiga, putri dari $\mathrm{KH}$. Hasan Abd Wafi satu-satunya menantu laki-laki pendiri PP. Nurul Jadid.

${ }^{36}$ Nyai Latifah adalah adik kandung dari Nyai Hamidah. Sedangkan Nyai Khadijatul Qodriyah adalah isteri dari KH. Abdul Hamid Wahid.
} 
di tahun 2009 yang lalu. Para Bu Nyai yang bertugas di lingkungan menjaga, merawat, dan melayani pondok pesantren tidak banyak mengambil kegiatan pemberdayaan di luar pondok pesantren. Berbeda dengan para Bu Nyai yang masih gres dan berusia muda. Mereka diperbolehkan untuk menghadiri penyuluhan dan memberikan pemahaman kepada masyarakat yang luas. Tidak dibatasi pada ruang lingkup lingkungan tertentu (sesuai pada paparan data yang penulis sebutkan di atas). Hal lain yang menarik mungkin diungkapkan adalah para Bu Nyai di PP. Nurul Jadid, Paiton tidak pernah mempersoalkan persepsi yang akan dikembangkan oleh masyarakat terhadap norma sosial yang berbeda. Padahal, sebagaimana diketahui lingkungan masyarakat Probolinggo tergolong pada masyarakat yang tradisional dalam pandangan keagaman. Bagi para Bu Nyai aktifitas tersebut dilaksanakan karena spesifik pada pemberdayaan perempuan. Jadi, tidak ada kepentingan untuk memaparkan alasan kegiatan tersebut. Apa yang dilakukan tidak melanggar normatifitas agama yang ada. Sekali lagi, sebab basisnya adalah gender (kelamin yang sama).

Jadi, jika boleh merangkai ulang, bagaimana konsepsi Islam dan gender, serta model pemberdayaan yang ada di PP. Nurul Jadid, Paiton, maka bisa diungkapkan dalam bahasa "institutional-Islamic gendered Stance and systemic empowerment". Artinya, dalam konteks pengayaan pemahaman gender di PP. Nurul Jadid, hal itu dilakukan melalui perangkat institusional; apakah itu kajian menggunakan riset Pusat Studi Wanita (PSW IAI Nurul Jadid) atau bisa menggunakan diskusi informal di kalangan para Ikatan Perempuan Yayasan PP. Nurul Jadid, Paiton. Desiminasi dan hasil diskursus tersebut kemudian yang terimplementasikan secara strategis kepada para masyarakat, baik itu di sekitar PP. Nurul Jadid, Paiton atau di dalam kehidupan masyarakat yang luas. Oleh karena sudah dikonstruk sedemikian rupa, maka mereka tentu akan memiliki cara efektif untuk mengubah paradigma negatif yang ada di masyarakat. Salah satunya misalnya, bagaimana mereka melakukan penyuluhan pemahaman gender dengan mengundang masyarakat sekitar ke pondok pesantren sebagai inkubasi pemahaman dan penyamaan persepsi antara apa yang diinginkan BuNyaidan masyarakat, secara partisipatoris. Selanjutnya, hasil diskusi tersebut kemudian dibawa sebagai materi umum di masyarakat. 


\section{Extended Roles; Perpaduan Aktivitas Pendidikan,Sosial, Ekonomi dan Kepentingan Politik Perempuan}

Sebagaimana sudah disebutkan dalam latar, penulis juga ingin menambahi kajian pemberdayaan ini pada aspek yang lebih luas. Asumsi penulis kala itu adalah, interaksi pemberdayaan dan kuatnya keyakinan masyarakat Probolinggo dengan tradisi keagamaan dan pondok pesantren, akan berimbas pada dimensi kehidupan yang lain, semisal; politik dan advokasi pada konflik-konflik yang ada di masyarakat. Pola hubungan antara patron-klien dalam teori politik praktis, bisa dijadikan konstruksi awal untuk mengkonstruksi extended roles pemberdayaan perempuan yang ada di PP. Nurul Jadid, Paiton. Sebagaimana data yang penulis dapatkan, di lingkungan ndalem PP. Nurul Jadid, Paiton ada dua Kyai yang secara aktif berada di dunia politik praktis, yakni; (alm) KH. Abdul Haq Zaini dan KH. Abdul Hamid Wahid. Kedua tokoh ini, dalam sejarah politik lokal, memiliki pengaruh yang sangat kuat. (alm) KH Abdul Haq Zaini sempat menjadi Dewan Syuro PKB Probolinggo dan Penggagas PKNU di Jawa Timur. Sedangkan KH. Abdul Hamid Wahid, sempat menduduki kursi ANggota DPR RI selama dua periode dari Partai Kebangkitan Bangsa.

Wafatnya KH. Abdul Haq Zaini menandakan pengaruh politik tersebut itu beralih ke Bu Nyai Firdausiyah. Masyarakat yang terbiasa meminta fatwa untuk menentukan pilihan politik kepada para kyai, akhirnya mengubahnya meminta fatwa itu pada Bu Nyai Fir, sapaan akrabnya. Oleh karena tuntutan masyarakat yang demikian, dia pun harus berusaha memahami dan mempelajari dinamika politik yang ada di Probolinggo atau secara spesifik di lingkungan Kecamatan Paiton. Kepada peneliti dia menyebutkan: "Karena sudah tidak ada, ibu-ibu itu biasanya bertanya pada saya tentang pilihan politik. Dari itu, mau tidak mau, suka tidak suka, saya harus berusaha untuk memberikan pencerahan kepada masyarakat bagaimana sebenarnya menentukan pilihan politik. Berbeda dengan Kyai yang punya partai saya biasanya lebih objektif untuk pilihan itu. Mereka diberi kebebasan dengan pilihan mereka sendiri. Saya memberikan pandangan kalau calon ini begini, kalau ibu ini begini, dan 
bisa jadi, saya juga memberikan pandangan berdasarkan jenis kelamin, meski jarang, tergantung calon". ${ }^{37}$

Demikian pula dengan Bu Nyai Khadijatul Qodariyah Wahid, isteri dari KH. Abdul Hamid Wahid. Keterlibatan suaminya di dunia politik praktis menjadikan dia terbiasa dengan dunia yang sarat dengan citera negatif ini. Namun, latar belakang pendidikan, organisasi, dan kematangan mentalitas dia sebagai seorang akademisi, mencipta corak baru di lingkungan Bu Nyai di PP. Nurul Jadid Paiton. Dia mampu mengemban semua tugas politik dan peranannya sebagai $\mathrm{Bu}$ Nyai di pesantren yang memiliki tanggung jawab sosial dan institusional dengan baik. Terlepas dari kematangan pribadinya, pada tahun 2014 yang lalu, akhirnya, dia mengikuti jejak suami dalam menggeluti dunia politik praktis. Sebagai salah seorang calon anggota DPD RI. Kehidupan di politik itu pulalah, membuatnya terbiasa dengan pemberdayaan perempuan di bidang politik. Strategi kampanyenya pun berbasis pada proses menggerakkan kelompok pemilih perempuan. Dia bersaing dengan Bu Nyai lain dari Jombang, yang melakukan gerakan politik serupa. Meski dia harus gagal, tapi keterikatan sebagai aktivis politik, masih memberikan ruang-ruang sosial untuk memberdayaan perempuan berbasis pada Islamicgendered Stance yang dibingkainya di Pusat Studi Wanita IAI Nurul Jadid, Paiton, dimana dia juga menjadi Pembina dari lembaga tersebut. $B u$ Nyai Khadijah Q Hamid juga sering diundang untuk mensosialisasikan peraturan-peraturan pemerintah dan program-program yang dicanangkan pemerintah dalam pemberdayaan perempuan.

Selain bidang politik, relasi bidang sosial dengan masyarakat juga menghasilkan kebergantungan masyarakat (khususnya para perempuan) terhadap Bu Nyai sebagai public figur yang dipercayai (trusted public figure). Imbasnya, Bu Nyai - hampir semuanya untuk bidang ini - diminta pertimbangan oleh masyarakat untuk menyelesaikan konflik yang dihadapinya. Misalnya, konflik perebutan tanah untuk industry di daerah PLTU atau konflik lahan untuk perluasan akses ketempat wisata. Peran Bu Nyai dalam bidang ini adalah melakukan advokasi pada ibu-ibu agar mau memahami apa yang semestinya menjadi hak-hak azali mereka. Disamping itu, Bu

${ }^{37}$ Wawancara dengan Nyai Firdausiyah pada tanggal 04 Juni 2017 
Nyai juga diberikan penyadaran tentang pola memahami kehidupan baru dan dampak sosiologis yang dihasilkan oleh perubahan ruang dan tempat yang ada di sekitarnya. Setelah memberikan pemahan, Bu Nyai juga melakukan komunikasi politik terhadap stake-holder yang bertanggung jawab untuk melaksanakan kegiatan atau program tersebut. Jadi, pemberdayaan perempuan di bidang politik dan advokasi ini memang cenderung atas permintaan masyarakat, bukan berasal dari inisiasi program yang dicanangkan oleh para $\mathrm{Bu}$ Nyai di lingkungan PP. Nurul Jadid, Paiton. Itulah sebabnya penulis menamainya sebagai peran tambahan Bu Nyai yang ada di PP. Nurul Jadid.

\section{E. Simpulan}

Pada kesimpulannya, kesadaran pemberdayaan berbasis gender Bu Nyai di PP. Nurul Jadid, Paiton didasarkan pada Islamic Gendered Stance, yang diintegrasikan melalui pembacaan ilmiah dan alamiah. Artinya, model pemberdayaan ini tidak untuk merusak konsepsi normative dan dogmatis tentang kodrat seorang perempuan. Lebih luas dari itu, pemberdayaan dilaksanakan seperti apa yang ditawarkan oleh Hall, yakni; sebuah model penyadaran, pembelajaran, peningkatan, dan penguatan terhadap nilai budaya, agama, keterampilan, kemandirian, dan kesadaran yang dimiliki oleh seorang perempuan. Melalui model seperti ini, maka tidak satupun perspektif Islam, dan budaya pesantren akan mengalami distruksi serta ditentang melalui gerakan pemberdayaan. Model-model penyadaran ini dikonsepsikan pada tiga bidang penting; pendidikan, sosial dan ekonomi. Pemberdayaan pada bidang pendidikan berbasis pada broad based educational gendered system (perluasan para perangkat keterampilan bagi perempuan). Sosial dan ekonomi lebih pada praktek terhadap apa yang dilaksanakan melalui pendidikan tersbeut.

Di PP. Nurul Jadid, Paiton juga ditemukan bahwa relasi yang terbangun melalui pemberdayaan di bidang pendidikan, sosial, dan ekonomi bisa berdampak pada pemberdayaan politik dan resolusi konflik. Hal ini tidak bisa dilepas dari sistem kepercayaan masyarakat tradisional terhadap kyai, bu nyai, dan orang-orang yang ada di dalamnya. Pada peran tambahan ini, model pemberdayaan 
yang dilakukan Bu Nyai berbasis pada community need assessment, bukan berdasarkan pada inisiasi yang dibuat oleh Bu Nyai sendiri. Maknanya, Bu Nyai sudah menjadi pemeran pengganti dari seorang kyai yang memiliki kesibukan di bidang politik. Bu Nyai menjadi penyelaras gagasan dan keinginan politik suci dari perempuan dan Islam itu sendiri. Serta, Bu Nyai juga diharapkan bisa hadir sebagai solver terhadap problem yang dihadapi masyarakat[.]

\section{REFERENSI}

Adnan, Kamila dkk. “Resistensi Perempuan terhadap tradisi-tradisi di Pesantren; Analisis Wacana Kritis Terhadap Novel Perempuan Berkalung Surban" dalam Jurnal KAWISTARA, Volume 6 Nomor 2 Tahun 2016.

Ambarwati, dan Aida Husna "Manajemen Pesantren Responsif Gender; Studi Analisis di Kepemimpinan Nyai Pesantren di Kabupaten Pati" dalam Jurnal PALASTREN, Volume 7, Nomor 2 Tahun 2014.

Bahri, Muhyiddin Zainul. "Peran Kepemimpinan Nyai di Pondok Pesantren; Studi Multi Situs di PP. Al Lathifiyah, Tambak Beras Jombang, PP. Nur Khadijah Denanyar Jomban, dan PP. Al Hikmah Kediri" dalam Jurnal SAINTEKBU: Sains dan Teknologi, Volume 7, Nomor 2 Tahun 2014.

Cholida, Noer. "Kepemimpinan Pada Pondok Pesantren (Studi Resistensi Bu Nyai Terhadap Patriarkhi Di Kediri)," Disertasi, Surabaya: UIN Sunan Ampel, 2014.

Dhofier, Zamakhsyari. Tradisi Pesantren; Studi Pandangan Hidup Kiai dan visinya mengenai masa depan Indonesia. Jakarta: LP3ES, 2011.

Faiqoh. "Nyai Agen Perubahan di Pesantren" dalam Jurnal Penelitian Pendidikan Agama dan Keagamaan Volume 3 Nomor 2 Tahun 2005.

Faqih, Mansour. AnalisisGenderdanTransformasiSosial. Yogyakarta: Pustaka Pelajar, 1999. 
Hall, C. Margaret. Women and Empowerment; Strategies For Increasing Authonomy. London: Himesphere Publishing Corp. 1992

http:/ / www.majalahsaksi.com/pdf.php?id=63 Pada 23 Maret 2017

Kartasasmita, Ginanjar. Pembangunan Untuk Rakyat. Jakarta:Pustaka CISENDO, 1996.

Malik, Hatta Abdul. "Kaderisasi Ulama' Perempuan di Jawa Tengah" dalam Jurnal At-Taqaddum, Volume 4, Nomor 1, Tahun 2012.

Malik, Jamaluddin (Ed.). Pemberdayaan Pesantren Menuju Kemandirian dan Profesionalisme Santri dengan Metode Daurah Kebudayaan. Yogyakarta: Pustaka Pesantren kerja bareng dengan Yayasan Kantata Bangsa, 2005.

Mufidah Ch. "Pandangan Santri Ma'had Aly tentang Pengarusutamaan Gender di Pesantren Salafiyah Syafi' iayh Sukorejo, Situbondo Jawa Timur" dalam Jurnal Islamica Volume 4 Nomor 1 Tahun 2009.

Mulia, Siti Musdah dkk. (Ed.) Keadilan dan Kesetaraan Jender Perspektif Islam. Jakarta: Tim Pemberdayaan Perempuan Bidang Agama Departemen Agama RI, 2001.

Mustaqim, Abdul. Paradigma Tafsir Feminis Membaca al-Qur>an dengan Optik Perempuan. Yogyakarta: Logung Pustaka, 2008.

nuruljadid.net

Oakley, Petter \& David Marsden. Approaches to Participation in RuralDevelopment. Geneva: t.p., 1984.

Qibtiyah, Mariatul. "Kepemimpinan Perempuan: Peran Perempuan dalam Jejaring Kekuasaan di Pondok Pesantren Aqidah Usymuni Terate Pandian Sumenep," Disertasi. Surabaya: UIN Sunan Ampel, 2014.

S Mahmudah Noorhayati, "Pemberdayaan Perempuan dan Emansipasi Gender (Studi atas Peran Nyai dalam pemberdayaan perempuan dan Emansipasi Gender di Pondok Pesantren Nurul Jadid, Paiton Probolinggo," Thesis, Surabaya: IAIN Sunan Ampel, 2009.

Sahay, Sushama. Women and Empowerment Aprroaches and Strategies. New Delhi: Discovery Publishing House, 1998. 
Sutatmi dan Siti Malikhah Towaf dkk, "Program Pendidikan Wirausaha berwawasan Gender berbasis Jasa Boga di Pesantren Salaf" dalam Jurnalekonomi Bisnis, Volume 16, Nomor 1 Maret 2011.

Tim Penyusun buku Panduan PSW IAI Nurul Jadid. Selayang Pandang Pusat Studi Wanita IAI Nurul Jadid. Probolinggo: LPM IAI Nurul Jadid Press, 2013.

Towaf, Siti Malikhah. Paparan hasil riset dalam Program dan Perencanaan Program Pemberdayaan Perempuan berwawasan Jender. Pelatihan Kepemimpinan Berwawasan Jender bagi Tim Penggerak PKK Kabupaten Gresik, Oktober 2003 dan 17-18 Juni 2004

Towaf, Siti Malikhah. Peran Perempuan, "Peran Perempuan, Wawasan Gender dan Implikasinya Terhadap Pendidikan Pesantren" dalam Jurnal Ilmu Pendidikan UM Malang Jilid 15, Nomor 3 Tahun 2008.

Umar, Nasaruddin. Argumen Kesetaraan Gender Perspektif al-Qur'an. Jakarta: Paramadina, 1999.

Yanggo, Huzaem Tahido. Membincang Feminisme Diskursus Gender Perspektif Islam. Surabaya: Risalah Gusti, 2000.

Wawancara dengan Nyai Firdausiyah pada tanggal 04 Juni 2017.

Wawancara dengan Nyai Khodijatul Qodriyah Hamid pada tanggal 04 Juni 2017. 